Photogallery

\title{
Asexual reproduction by marginal budding in the tropical corallimorpharian, Ricordea yuma (Corallimorpharia; Ricordeidae)
}

\section{Mei-Fang LIN ${ }^{1}$, Chaolun Allen CHEN $^{2, *}$, and David J. MILLER ${ }^{1, *}$}

${ }^{1}$ ARC Centre of Excellence Coral Reef Studies, James Cook University, Townsville, 4811 Australia

${ }^{2}$ Biodiversity Research Centre/Taiwan International Graduate Program-Biodiversity, Academia Sinica, Taipei, 115 Taiwan

* Corresponding author: A. Chen, D.J. Miller

E-mail: cac@gate.sinica.edu.tw, david.miller@jcu.edu.au

Communicated by Hiroya Yamano (Environment and Conservation Editor)

Keywords "False corals", Corallimorpharia, Anthozoa, reproduction, marginal budding

Corallimopharians are a group of anthozoans that can rapidly monopolise patches of shallow water substrate on tropical coral reefs and persist as the dominant benthos after frequent disturbances (Chadwick-Furman and Spiegel 2000). One factor contributing to the ability to rapidly colonize available substrate is the diverse range of asexual reproductive strategies displayed by various corallimorphs, including pedal laceration, longitudinal fission and inverse or marginal budding (den Hartog 1980; Chen et al. 1995; Chadwick-Furman and Spiegel 2000). Of these, marginal budding, a process whereby one or more sections of the margin, including part of the oral disk with a mouth and tentacles, column, and pedal
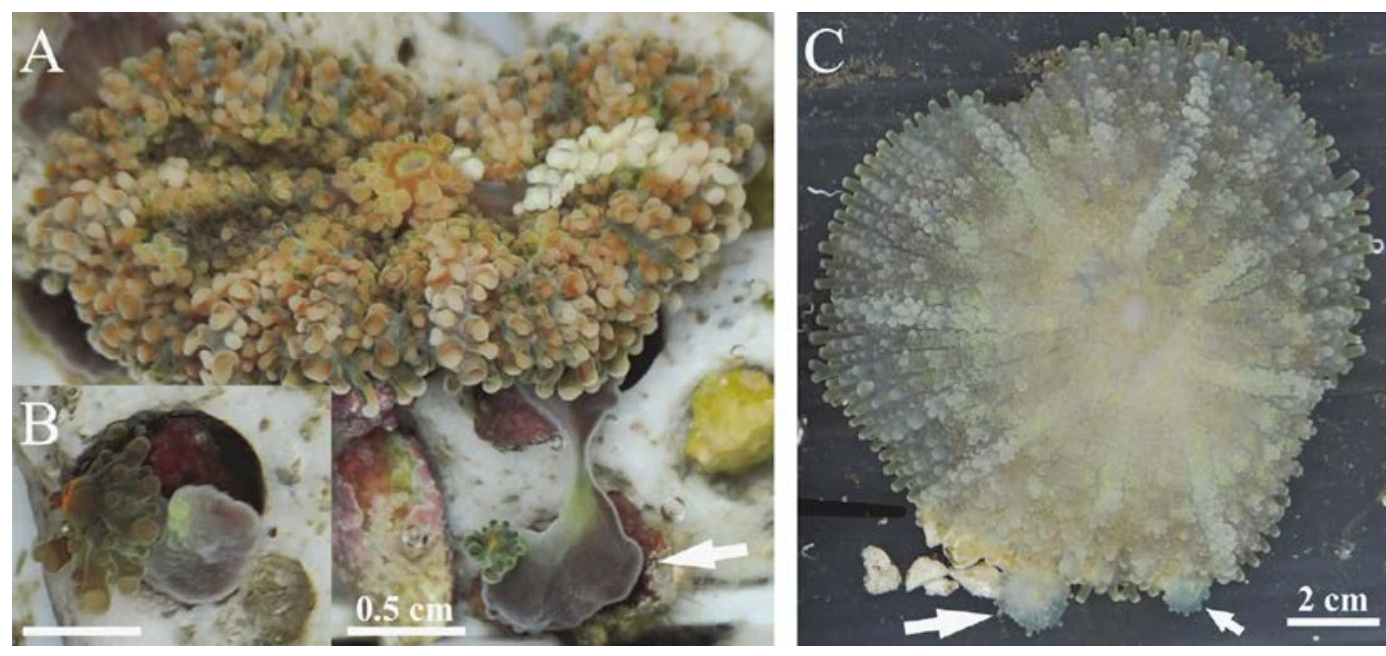

Fig. 1 Marginal budding of Ricordea yuma in aquaria. A) A mature individual with a developing polyp, generated by marginal buddings, still attached to the parent. B) Days later the new polyp is fully detached, has increased in size and developed more tentacles. C) A large R. yuma individual that had been maintained in the dark, with two new marginal buds 
disk, detach from the mother poly, has so far only been described in the Red Sea corallimorpharian, Rhodactis rhodostoma, although Chadwick-Furman and Spiegel (2000) speculated that it may occur in other common corallimorpharians.

In December, 2012, marginal budding was observed for four Ricordea yuma specimens in a wide range of sizes (3.7$9.0 \mathrm{~cm}$ diameter) of a total of 17 individuals that had been collected from the Great Barrier Reef $\left(18^{\circ} 25^{\prime} 35.20^{\prime \prime} \mathrm{S}\right.$, $146^{\circ} 41^{\prime} 10.91^{\prime \prime} \mathrm{E}$ ) and maintained in aquaria for 20-28 days under ambient conditions (Fig. 1A). Within 20 days, the scarred area around the new bud had healed, and the mouth and tentacles of the budded individual were fully developed (Fig. 1B). Marginal budding was also observed in 2 of 3 R. yuma polyps that had been maintained in darkness for 49 days (Fig. 1C). These observations of marginal budding in a common Indo-Pacific corallimorpharian confirm that this reproductive strategy is not restricted to the Red Sea species, and suggest that it may occur more generally.

\section{Acknowledgments}

We thank the Reef HQ Great Barrier Reef Aquarium for providing samples.

\section{References}

Chadwick-Furman NE, Spiegel M (2000) Abundance and clonal replication in the tropical corallimorpharian Rhodactis rhodostoma. Invertebrate Biol 119: 351-360

Chen CA, Chen C-P, Chen I-M (1995) Sexual and asexual reproduction of the tropical corallimorpharian Rhodactis (=Discosoma) indosinensis (Cnidaria: Corallimorpharia) in Taiwan. Zool Stud 34: 29-40

den Hartog JC (1980) Caribbean shallow water Corallimorpharia. Zoologische Verhandelingen, Leiden 176: 11-18

Received: 18 August 2013/Accepted: 8 November 2013

(C) Japanese Coral Reef Society 